\title{
Subject 30
}

\author{
Meadows and Pastures \\ $12^{\text {th }}$ suite
}

June 1959

\section{The effect of potash fertilization on dry matter production of permanent pasture throughout the season}

\author{
By P. de Vries and C. T. de Wit \\ Netherlands J. agric. Sci. 6, No. 2, 124-130 (1958)
}

\section{Summary}

Varying amounts of potassium were applied five times a year to a permanent pasture on sandy soil, a different part of the field being chosen on each occasion. The potassium availability of the soil at the time of potassium application was kept at approximately the same level. The effect and after-effect on yield and $\mathrm{K}_{2} \mathrm{O}$ uptake of the potash fertilization is studied. The uptake-yield curves, the fertilizer rate-uptake curves and the fertilizer rate-yield curves of this first to fifth cut are shown in the first, fourth and second quadrant of figure 1.

It is found that:

a) the relation between uptake and yield differed in successive cuts, but was the same as regards the effect and after-effect of the potassium dressing;

b) the effect of potash fertilization in autumn depended to a large extent on the withdrawal of potassium with previous cuts;

c) the existence of a causal relation between temperature and the effect of potassium fertilization is not proved;

d) the availability of potassium at a K-value of about 16 was almost sufficient to enable any growth to take place;

e) the uptake from soil was not determined by growth;

f) the recovery of the potassium fertilizer was to a large extent dependent on growth;

g) except for the first cut, the uptake was greater than that needed for reasonable growth;

h) the most favourable treatment would have been a dressing of about $200 \mathrm{~kg} \mathrm{~K} \mathrm{~K}_{2} \mathrm{O}$ per ha in spring only.

\section{Introduction}

Under Dutch conditions it may be advisable to apply potassium fertilizers to permanent pastures both in spring and in the course of the growing season. "t Hart and Van der Paauw (1) concluded that there was no distinct yield response to summer dressing. On the other hand, ' $t \operatorname{Hart}(2,3)$ found that the reaction to potassium fertilizer, expressed as percentages of the control, was higher in spring and autumn than in summer, and he concluded that this difference in reaction was due to the temperature. 


\section{The experiment}

In 1955 an experiment was carried out on a permanent pasture in order to evaluate the effect on grass production of different amounts of potassium applied at different times of the year. The upper five centimetres of the soil contained $9 \%$ soil particles smaller than $16 \mu, 10 \%$ organic matter and $0 \%$ calcium carbonate. The $\mathrm{pH}$ (in $\mathrm{KCl}$ ) was 5.3 , the phosphate availability was high $\left(\mathrm{P}\right.$-citr. $=65$ ) and the availability of potash very low (K-value $\left.=14^{*}\right)$.

Apart from three replications of the treatments and six of the controls, the experiment comprised 25 plots. Each plot was mown five times, viz. on May 31, July 11, August 16, September 16 and October 24. The plots were grouped at random in five blocks of five plots. In spring, or directly after the first, second, third and fourth cut respectively, the plots of one of the blocks, which, except for the compensatory dressing (see below), had not been previously fertilized, were dressed with $0,20,60,120$ and $200 \mathrm{~kg} \mathrm{~K}{ }_{2} \mathrm{O}$ per hectare in the form of $40 \%$ muriate of potassium. This treatment is called the experimental treatment.

Consequently, three kinds of plots may be distinguished:

a) the plots which at first were not given experimental dressings (these are the A-plots),

b) the plots which received the experimental treatment at the beginning of the growth of the cut (the B-plots) and

c) the plots which received the experimental treatment before a previous cut (the C-plots).

At the time of each cut there were five B-plots. At the time of the first cut there were 20 A-plots and no C-plots, whereas with each cut the number of C-plots increased by five and the number of A-plots decreased by five.

To keep the potassium level of the soil on the B-plots approximately the same at the time of the experimental treatment, at the beginning of growth each A-cut was treated with $40 \mathrm{~kg} \mathrm{~K}_{2} \mathrm{O}$ per hectare. This quantity should compensate the expected withdrawal of potassium from the soil. The withdrawal actually varied from $43-50 \mathrm{~kg} \mathrm{~K} \mathrm{~K}_{2} \mathrm{O}$ per hectare. It was found that the $\mathrm{K}$-value of the soil immediately prior to the experimental treatments was 14 , $13,14,19$ and 19. The yields of the A-plots are not further considered in this paper.

In spring $80 \mathrm{~kg} \mathrm{P} \mathrm{O}_{5}$ per hectare was applied in the form of double superphosphate. Each cut was dressed with $30 \mathrm{~kg} \mathrm{~N}$ per hectare in the form of lime ammonium nitrate. The first cut received the same quantity of nitrogen in addition as a top dressing because growth started late in the spring.

The sward was uniform and contained in the first cut $53 \%$ Lolium perenne, $10 \%$ Festuca pratensis, $19 \%$ Poa trivialis, a trace of clover, and $4 \%$ weeds. Details on weather and growth are given in table 1.

The dry matter yields and potassium and nitrogen contents were determined of each plot and each cut.

* To determine the K-value of sandy soils, an amount of dry, screened soil, corresponding to 6.25 grams organic matter, is shaken in 300 c. c. $0.1 \mathrm{n} \mathrm{HCl}$ for one hour. Potassium in extraction liquid is shown as multiples of $0.09 \mathrm{~kg} \mathrm{~K} \mathrm{O}_{2} \mathrm{O}$ per $1000 \mathrm{~kg}$ organic matter. The classification is as follows: $\angle 15=$ very low, $16-25=$ low, $26-35=$ moderate, $36-45=$ high and $>45$ very high. 
Monthly communications by the International Potash Institute, Berne (Switzerland)

Table 1

\begin{tabular}{|c|c|c|c|c|c|}
\hline Cut & 1st & 2nd & $3 r d$ & 4th & 5 th \\
\hline $\begin{array}{l}\text { Time of cutting (1955) } \ldots \ldots \ldots \ldots \ldots \ldots \\
\text { Average temperature, }{ }^{\circ} \mathrm{C}\end{array}$ & $31 / 5$ & $11 / 7$ & $16 / 8$ & $19 / 9$ & $24 / 10$ \\
\hline a) $-5 \mathrm{~cm} \ldots \ldots \ldots \ldots \ldots \ldots \ldots \ldots$ & 10 & 15 & 20 & 18 & 12 \\
\hline 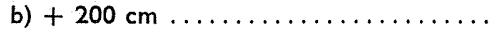 & 9 & 15 & 18 & 17 & 12 \\
\hline Number of growing days $\ldots \ldots \ldots \ldots \ldots$ & $46 *$ & 41 & 36 & 34 & 35 \\
\hline $\begin{array}{l}\text { Precipitation, } m m \ldots \ldots \ldots \ldots \ldots \ldots \\
\text { Yield on application of } 40 \mathrm{~kg} \mathrm{~K}{ }_{2} \mathrm{O} / \mathrm{ha}\end{array}$ & 91 & 61 & 70 & 34 & 89 \\
\hline a) $\mathrm{kg}$ dry matter $/ \mathrm{ha} \ldots \ldots \ldots \ldots \ldots$ & 2320 & 2300 & 1440 & 1260 & 920 \\
\hline b) kg dry matter/ha day.... & 50 & 56 & 40 & 37 & 26 \\
\hline Water level in soil, $\mathrm{cm} \ldots \ldots \ldots \ldots \ldots$ & -47 & -67 & -81 & -99 & -61 \\
\hline
\end{tabular}

* Growth is assumed to have started on April 15.

\section{A graphical representation of the results}

The experimental results are presented in figure 1 , in a manner similar to that employed by the second author (De Wit, 4). This figure shows three quadrants (marked I, II and IV). In the first quadrant, dry matter yield is placed

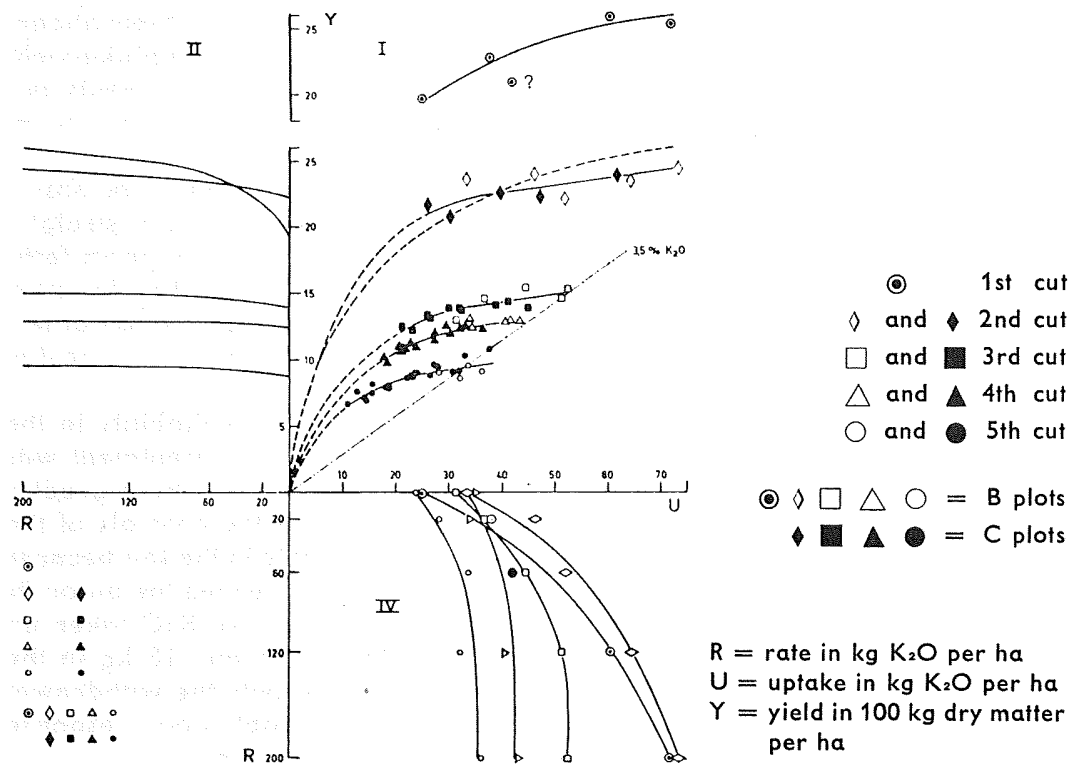

Figure 1 The relationships between amount of potassium applied, the potassium uptake and the dry matter yield in the five successive cuts of the experiment 
on the vertical axis and the uptake of potassium on the horizontal axis. This uptake was calculated by multiplying the dry matter yield by the potassium percentage content of this yield. The five groups of points relate to the first to fifth cuts. The black dots represent the C-plots and the open dots the Bplots. To avoid congestion the observations for the first cut are shown separately. The curve representing the relation between uptake and yield of this first cut is also shown on the original scale, but dotied to distinguish this curve from the similar one for the second cut.

In the fourth quadrant the amount of fertilizer applied is shown on the vertical axis and the uptake on the horizontal axis. The points in this quadrant relate to the B-plots of the first to fifth cuts only. The $\mathrm{C}$-plots cannot be evaluated on a basis of fertilization since these plots relate to the after-effect of the experimental treatments of previous cuits.

In the second quadrant dry matter yield is plotted on the vertical axis and amounts of fertilizer applied on the horizontal axis. The curves in this quadrant follow from those in the first and fourth quadrant.

The difference between the uptake on fertilized and unfertilized plots is termed, not extremely correctly, the uptake from fertilizer. The recovery is defined as this uptake divided by the amount of potassium applied and ranges from 0 to 1.

\section{Discussion}

The points in the first quadrant, both for the B- and C-plots, scatter for each cut around the same freehand curve drawn through these observations and the origin. The origin is included to emphasize the fact that at zero yield the uptake is also zero. The curve between the origin and the observational points is arbitrary and therefore dotted. The form of these uptake-yield curves is similar to those of other potassium fertilization experiments (4). Apparently the uptake-yield relation depends in this case on the period of growth, but not on the time at which potassium is applied.

The uptake-yield curves of the second to fifth cut in the region of observations on the B-plots (open dots) are approximately parallel and straight. The yield increase is $5.5 \mathrm{~kg}$ dry matter for each $\mathrm{kg} \mathrm{K}_{2} \mathrm{O}$ taken up from fertilizer. This yield increase for the first cut is about $14 \mathrm{~kg}$ dry matter for each kilogramme $\mathrm{K}_{2} \mathrm{O}$ taken up from fertilizer. Whether or not application of fertilizer resulted in a higher uptake, except for the first cut the yield increase due to this higher uptake was low in any case.

It should be remembered, however, that the potassium availability in the soil was kept at the same level at the time the experimental treatment was applied to the B-plots. The increase in dry matter production was much greater on those C-plots, where the uptake was smaller than on the controls of the B-plots. On these C-plots there was less potassium available in the soil because of the withdrawal in the previous B- and C-cuts, which exceeded the amounts applied in the experimental treatment. On those plots each $\mathrm{kg} \mathrm{K} \mathrm{K}_{2} \mathrm{O}$ taken up caused an increase in dry matter production of $16,17,15$ and $18 \mathrm{~kg}$ in the second to fifth cut. Hence if fertilizer is applied in spring only the withdrawal during spring and summer may be so high that a reasonably good response to potassium fertilization may be expected again in the autumn. 
Table 2

\begin{tabular}{|c|c|c|c|c|c|c|c|}
\hline \multirow{3}{*}{ Cut } & \multirow{2}{*}{\multicolumn{2}{|c|}{$\begin{array}{l}\mathrm{Kg} \text { dry matter per } \mathrm{kg} \\
\mathrm{K}_{2} \mathrm{O} \text { taken up within } \\
\text { the region of the }\end{array}$}} & \multirow{2}{*}{\multicolumn{4}{|c|}{$\begin{array}{c}\text { Recovery } \\
\text { (B-plots) } \\
\text { Application in kg K } \mathrm{K}_{2} \mathrm{O} / \mathrm{ha}\end{array}$}} & \multirow{3}{*}{$\begin{array}{c}\begin{array}{l}\mathrm{Kg} \text { dry matter per } \mathrm{kg} \\
\mathrm{K}_{2} \mathrm{O} \text { applied (B-plots) }\end{array} \\
\begin{array}{c}\text { Application } \\
\text { in } \mathrm{kg} \mathrm{K} \mathrm{K}_{2} \mathrm{O} / \mathrm{ha}\end{array} \\
120\end{array}$} \\
\hline & & & & & & & \\
\hline & B-plots & C-plots* & 20 & 60 & 120 & 200 & \\
\hline $1 \mathrm{st}$ & 14 & - & 0.50 & & & & \\
\hline 2nd & 5.5 & $\overline{16}$ & 0.43 & $\begin{array}{l}0.30 \\
0.34\end{array}$ & 0.26 & 0.20 & $\begin{array}{l}4.2 \\
1.4\end{array}$ \\
\hline $3 \mathrm{rd}$ & 5.5 & 17 & 0.25 & 0.22 & 0.16 & 0.11 & 0.9 \\
\hline 4 th & 5.5 & 15 & 0.13 & 0.11 & 0.07 & 0.05 & 0.4 \\
\hline 5 th & 5.5 & 18 & 0.15 & 0.13 & 0.09 & 0.06 & 0.5 \\
\hline
\end{tabular}

* Only C-plots in which the uptake was smaller than on the controls of the B-plots

The more favourable slope of the uptake-yield curve in the region of the C-plots shows that the effect of potassium fertilization on the later cuts of the B-plots would have been much greater if the compensatory amounts on the A-plots had not been given.

The recoveries of the four applications in all cuts, as read in the fourth quadrant, are given in the fourth to seventh column of table 2.

The recovery decreased both with increasing applications in successive cuts. As the effect of all applications was qualitatively the same, we will only consider here the application of $120 \mathrm{~kg} \mathrm{~K} \mathrm{~K}_{2} \mathrm{O}$ per ha. The kilogramme dry matter obtained for each kilogramme $\mathrm{K}_{2} \mathrm{O}$ applied at a rate of $120 \mathrm{~kg}$ per hectare, given in column eight of table 2, is calculated by multiplying the recovery (sixth column) by the slope of the uptake-yield curve of the B-plots (second column). The yield response decreased with successive cuts, since there is a decrease in both the recovery and the slope of the uptake-yield curve.

Under conditions prevailing in Holland potassium fertilization only pays if at least $3 \mathrm{~kg}$ dry matter is obtained for each kilogramme $\mathrm{K}_{2} \mathrm{O}$ applied. Simple but laborious calculations show that the best treatment would have been one application of $200 \mathrm{~kg} \mathrm{~K}{ }_{2} \mathrm{O}$ per ha in spring.

Table 3 shows the calculated yields and uptakes in this case and those obtained on the control.

Although this is not the case here, it appears that the availability of potassium may be so low that the most favourable treatment is an application in spring and a (generally smaller) application in late summer. The availability of potassium in the soil has to be very low before it is favourable to apply potassium at each cut. (It should be remembered that in Holland many highproducing fields have a low clover content).

'f Hart (3) concluded, that the reaction of grass to $\mathrm{K}_{2} \mathrm{O}$ dressings depends on the temperature during growth, the reaction being higher at low and lower at high temperatures. Average soil temperatures at $5 \mathrm{~cm}$ during the growth of the first to fifth cut were $10,15,20,18$ and $12^{\circ} \mathrm{C}$ in the present experiment; 
Table 3

\begin{tabular}{|c|c|c|c|c|}
\hline \multirow{2}{*}{ Cut } & \multicolumn{2}{|c|}{ O kg $\mathrm{K}_{2} \mathrm{O}$ per ha in spring } & \multicolumn{2}{c|}{$200 \mathrm{~kg} \mathrm{~K}_{2} \mathrm{O}$ per ha in spring } \\
\cline { 2 - 5 } & $\begin{array}{c}\text { yield kg } \\
\text { dry matter/ha }\end{array}$ & $\begin{array}{c}\text { uptake } \mathrm{kg} \\
\mathrm{K}_{2} \mathrm{O} / \mathrm{ha}\end{array}$ & $\begin{array}{c}\text { yield } \mathrm{kg} \\
\text { dry matter/ha }\end{array}$ & $\begin{array}{c}\text { uptake } \mathrm{kg} \\
\mathrm{K}_{2} \mathrm{O} / \mathrm{ha}\end{array}$ \\
\hline 1st & 1940 & 25 & 2600 & 72 \\
2nd & 2080 & 25 & 2370 & 62 \\
3rd & 1180 & 20 & 1430 & 39 \\
4 th & 1000 & 18 & 1230 & 32 \\
5th & 630 & 10 & 840 & 20 \\
\hline Total & 6830 & 98 & 8470 & 225 \\
\hline
\end{tabular}

average air temperatures at 2 meters were $9,15,18,17$ and $12^{\circ} \mathrm{C}$ respectively. The yield increases of the first to fifth cut on the B-plots due to $200 \mathrm{~kg}$ $\mathrm{K}_{2} \mathrm{O} / \mathrm{ha}$ were $660,220,110,50 \cdot$ and $80 \mathrm{~kg}$ dry matter/ha. These responses are not correlated to the temperature. The difference in yield between the plots which received $200 \mathrm{~kg} \mathrm{~K} 2 \mathrm{O} / \mathrm{ha}$ in spring only and those which received no potassium may also be considered. These differences are 660, 290, 250, 230 and $210 \mathrm{~kg}$ dry matter/ha respectively and are also uncorrelated to the temperature. The after-effect in autumn of $200 \mathrm{~kg} \mathrm{~K}{ }_{2} \mathrm{O} / \mathrm{ha}$ applied in spring seems higher than the effect of $200 \mathrm{~kg} \mathrm{~K}$ O/ha applied in autumn. This is due to the decline of the yield on plots which received no potassium; this decline in yield was caused by the withdrawal of potassium with the previous cuts.

't Hart does not compare absolute yield increases, but only yield increases expressed in percentages of the control. In our case these percentages are 34, $10,7,4$ and $9 \%$ on the B-plots which received $200 \mathrm{~kg} \mathrm{~K}{ }_{2} \mathrm{O} / \mathrm{ha}$, and 34,14 , 21,23 and $33 \%$ on the plots which received $200 \mathrm{~kg} \mathrm{~K}{ }_{2} \mathrm{O} / \mathrm{ha}$ in spring only. These latter percentages are correlated to the temperature. The reason for this correlation is that the yield on the control decreased in course of time, because the amounts of potassium withdrawn were not replenished. Consequently the correlation to temperature does not prove the existence of a causal relation between temperature and the effect of potash fertilization.

Table 4 shows that the uptake of $\mathrm{K}_{2} \mathrm{O}$ from the B-plots not fertilized with potassium (controls) is not correlated to the yield, whereas the recovery from an application of, for instance, $120 \mathrm{~kg} \mathrm{~K}{ }_{2} \mathrm{O}$ per ha is positively correlated to the yield.

The absence of any correlation between yield and uptake from soil on the controls indicates that:

a) the availability of potassium at a $\mathrm{K}$-value of around 16 was nearly sufficient to permit any growth, and

b) the uptake from the soil was not determined by growth, but probably by the rate at which the potassium was liberated in a form available to the plant. 
Monthly communications by the International Potash Institute, Berne (Switzerland)

$30 / 12$

Table 4

\begin{tabular}{|c|c|c|c|c|}
\hline Cut & $\begin{array}{c}\text { Uptake on } \\
\text { control in } \\
\mathrm{kg} \mathrm{K} \mathrm{K}_{2} \mathrm{O} / \mathrm{ha}\end{array}$ & $\begin{array}{c}\text { Yield on control } \\
\text { in } \mathrm{kg} \\
\text { dry matter/ha }\end{array}$ & $\begin{array}{c}\text { Recovery } \\
\text { at } 120 \mathrm{~kg} \\
\mathrm{~K}_{2} \mathrm{O} / \mathrm{ha}\end{array}$ & $\begin{array}{c}\text { Yield in } \mathrm{kg} \\
\text { dry matter/ha } \\
\text { at } 120 \mathrm{~kg} \mathrm{~K} \mathrm{O} / \mathrm{ha}\end{array}$ \\
\hline & 25 & 1940 & 0.30 & 2450 \\
1st & 34 & 2220 & 0.26 & 2490 \\
2nd & 32 & 1380 & 0.16 & 1500 \\
3rd & 34 & 1240 & 0.07 & 1280 \\
4th & 24 & 880 & 0.09 & 960 \\
5th & 24 & & & \\
\hline
\end{tabular}

The positive correlation between recovery and yield and the low yield response to a potassium fertilizer indicate that where potassium is applied:

a) except for the first cut the uptake was larger than that required for reasonable growth, and

b) the recovery was largely dependent on the growth rate of the cuts.

In quadrant IV of figure 1 the rate-uptake curves of the last three cuts approach a maximum, whereas this is not the case for the curves of the first two cuts. The end points of the uptake-yield curves (quadrant I) of the third to fifth cut are found approximately on the same line through the origin. The percentage content of $\mathrm{K}_{2} \mathrm{O}$ indicated by this line is $3.5 \%$. It seems that whatever the potassium application the plant mass of this experiment could not store more than $3.5 \% \mathrm{~K}_{2} \mathrm{O}$. This is low compared with potassium contents occuring in other experiments. In the first two cuts, of which the curves in quadrant IV do not approach a maximum, this content of $3.5 \% \mathrm{~K}_{2} \mathrm{O}$ was not reached. If is possible that this difference between the first two and the last three cuts was due to the fact that the first two were in the reproductive and the last three in the vegetative stage of development at the time of harvesting.

De Wit (4, page 26) was unable to find examples of experiments in which the upiake was limited by the "storage capacity" of the plants, but in this case no attention was paid to grass in its vegetative stage of development. It was, however, mentioned that in such cases the "compensation function", giving the relation between uptake from broadcast and placed fertilizer, cannot be applied.

\section{Bibliography}

1. Hart, M. L. 't, and Van der Paauw, F.: Landbouwvoorlichtingsdienst, Medeling No 30 (1942)

2. Hart, M. L. 't, and Van der Paauw, F.: Versl. landb. Onderz. 's Grav. 54, N' 7 (1948)

3. Hart, M. L. 't, and Van der Paauw, F.: Plant \& Soil 1, pp. 264-270 (1949)

4. Wit, C. T. De: Versl. landb. Onderz. 's Grav. 59, No 4 (1953) 
